\title{
Evaluation Criterion for the Quality of Government Services
}

\author{
Aleksandr Yurevich Pavlov \\ Associate professor of the chair "Applied economics", Penza State Technological University \\ Penza, Russia; E-mail: pavlov_85@bk.ru \\ Vera Nikolaevna Batova
}

Associate professor of the chair "Economics and management", Penza State Technological University Penza, Russia; E-mail: batova.v.n@yandex.ru

\author{
Alexander Yurevich Sokolov \\ Professor, head of the chair "Administrative and municipal law", Saratov State Law Academy \\ Saratov, Russia; E-mail: aysockolov@mail.ru
}

Natalia Nikolaevna Kovalyova

Professor of the chair "Administrative and municipal law", Saratov State Law Academy

Saratov, Russia; E-mail: kovaleva.natalia@mail.ru

\section{Andrey Vladimirovich Kolesnikov}

Associate professor of the chair "Administrative and municipal law", Saratov State Law Academy

Saratov, Russia; E-mail: kaviras@yandex.ru

\section{Doi:10.5901/mjss.2015.v6n6p381}

\section{Abstract}

Formation of criteria of an assessment of quality of the state services allows to perform measurements in the field of satisfaction of citizens with the received services and forms a basis for identification of weak places of local government and is a basis for further adoption of administrative decisions on its improvement. A problem of the quality of government services' evaluation is a new phenomenon for the Russian legal reality. Its consideration deals with a number of problems the solution of which is methodologically necessary. For today the problem of absence of a single methodology of government services' quality evaluation is clear. Thus there is a need to create a methodology that takes into account all important for consumers interior and exterior characteristics of the services' process provision. The nowness of this article is determined by the necessity to improve the quality of government services. The article concludes that the systematization of quality evaluation criteria is important not only to facilitate the monitoring of government services' quality, but also for a more effective allocation of budgetary resources. The analysis of methods to evaluate the quality of services developed in the specialized literature led to a conclusion that the success and applicability of a specific methodology for evaluation the quality of government services depends on the completeness and optimally designed system of quality criteria. This paper proposes a set of criteria for evaluation the quality of government services.

Keywords: government services, the quality of government services, the properties of government services, quality evaluation criteria, monitoring of the quality of government services

\section{Introduction}

The main part of the quality control mechanism is a development of a single approach to evaluation the quality of government services. It allows you to find out how citizens are satisfied by received services, to identify weak points in the process and to improve further decision-making management in that process.

A problem of the quality of government services' evaluation is a new phenomenon for the Russian legal reality. Its consideration deals with a number of problems the solution of which is methodologically necessary. They are: 
- the ability to measure and evaluate the quality of governmental services;

- the need to select methods of its evaluation ;

- the need to distinguish government services from services in a sense of civil law;

- an analysis of the possibility to use the techniques and tools which are applied in the non-public area while government services' characteristics are measured.

For today the problem of absence of a single methodology of government services' quality evaluation is clear. Thus there is a need to create a methodology that takes into account all important for consumers interior and exterior characteristics of the services' process provision.

\section{Methods and Materials}

The implementation of the objectives were achieved on the basis of an analysis of the main provisions of the legislation of the Russian Federation. The authors used when writing the article abstract, logical and monographic methods. The authors used materials of the periodical press, legislative acts of the Russian Federation, the Internet - resources.

\section{Main Text}

Government services provided by public entities are diverse and specific. In connection with this some common criteria of quality and accessibility of services should be developed and general method of determining the indicators should be worked out. In its turn, an analysis of government services' administrative regulations led to the conclusion of gaps in this area.

The Federal Tax Service administrative regulation on the state registration of cash registers used by organizations and sole proprietors [1] focuses on claims indicators, such as absence of:

- complaints against actions (failure to act) of the territorial tax service specialists who provide governmental services;

- complaints against incorrect, inattentive attitude to applicants of territorial tax service specialists who provide governmental services;

- judicial acts invalidating the decisions of Federal Tax Service of Russia (hereinafter FTS of Russia) and its territorial bodies of registration, re-registration, removal from the registration of cash registers.

Such quality claim criterion is also used in one another regulation, [2] adopted by the Ministry of Finance of the Russian Federation

Should be mentioned that such quality claim evaluation criteria used by many federal and regional executive authorities [3] as a determining factor.

Seems that this criterion does not fully characterize the quality of services actually provided, because people prefer not to deal with tedious and meaningless in their opinion complain procedures against the acts of governmental servants.

Other Ministry of Finance regulations state a list of applicants' rights when they apply for services or provide some inconcrete portions of law which regulate ensuring of the quality of services in paragraph "Indicators of quality and accessibility of government services" [4].

The gaps mentioned before are typical for administrative regulations of a number of other state bodies, [5] in which the parameters of quality and accessibility of government services are paid little attention to. Obviously the problem has little working out what means that authorities are not interested to solve the problem.

That is why systematization of quality evaluation criteria in terms of their significance is important not only to facilitate the monitoring of the government services' quality, but also for a more effective allocation of budgetary resources.

The analysis of methods to evaluate the quality of services developed in the specialized literature [6] led to a conclusion that the success and applicability of a specific methodology for evaluation the quality of government services depends on the completeness and optimally designed system of quality criteria.

Therefore requirements for the government services quality should be clearly defined and expressed in characteristics which will evaluate quantitative and qualitative parameters of services. Concerning the quality of services, this concept should be understood in a broad sense, which includes the process of government officials' and consumers' cooperation. That is why this procedure shall be expressed in characteristics that in the best way indicate the factors affecting the final evaluation of the applicant.

Working-out the most perfect system of quality indicators that reflect all significant aspects of government services 
is necessary for both theoretical development and for direct use in practice. It becomes more important when we deal with the quality of government services' management. So the analysis and control of the process of services' provision is a necessary condition to improve their quality to the level set in the standards.

The results of opinion polls [7] carried out on federal level from 2008 to 2012 by different independent organizations identified main problems with which the recipients of government services are faced. In other words it is the factors which form negative attitude of the population towards government authorities. This list is built according to the degree of importance of each parameter:

- a large number of queues when one applies to bodies that provide services;

- $\quad$ applicants need to carry out a large number of appeals to get a government service;

- $\quad$ some citizens receive government services bypassing the queue;

- long-term provision of government services;

- indifferent attitude of government servants to applicants;

- lack of sufficient information about services provided and the necessary actions to apply for it;

- low level of professional training of workers;

- places of reception and waiting for visitors are underresourced.

The opinion polls of citizens mentioned before show that if to focus on accelerating the provision of government services and reduce a number of required applications of citizens it will lead to greater effect than similar measures aimed to improve the comfort of citizens' reception place.

The legal literature provides a number of definitions of "government services' quality". There are two basic definitions of that phenomenon worth to be mentioned. The first one is a set of services' properties that can satisfy the needs of citizens. The second one is fulfilment of obligatory requirements established by the quality of government services.

The first definition takes into account the opinion of direct consumers, which is the interior of the government services' provision.

The second one characterize the services' provision in terms of compliance with established rules, describing the government services with the exterior.

The most complete and correct understanding of the government services' quality should be formed using both definitions. In this regard, the government services' quality is a set of interior (citizens' opinion) and exterior (compliance of services actually provided to the requirements set in the standards) characteristics.

Usually in practice, the interior components are brought in to evaluate the quality of services more often than other ones. For example, criterion "compliance with standards of government services' provision" is widespread [8]. In the same time it does not provide an important element of the quality characteristics as consumer's satisfaction.

\section{Conclusion}

Based on the foregoing, a new system of quality evaluation criteria of government services is proposed. This system is built according to the degree of importance of each parameter for recipients of government services. The importance of each parameter is determined by opinion polls which are regularly carried out [9].

It seems possible to distinguish five types of quality criteria of government services that allow to take into account interior and exterior components in a more complete way when it is evaluated. It is:

- the process of staff and recipients' of government services cooperation (the number of required applications to the governmental body to receive government services, friendly and discreet treatment with the applicants, the waiting time in the queue, the time required to carry out actions preceding and necessary to get government services, time spent at the sending or receiving documents, total time spent since the first application for service till the result, the carrying capacity (per working day), no legitimate complaints of citizens against actions or decisions of officials responsible for the provision of government services, the presence of telephone hotlines to inform citizens, the existence of an automated control queue system of applicants)

- the result of the government services (the degree of satisfaction of citizens by a government services, compliance with the standard of government services, the lack of come into force court decisions or decisions of higher authorities which abolish, change in part or entirely the results of government services, the number of government services provided in accordance with the defined in the standards terms of the total number of services provided);

- personnel (level of professional training, communication skills and ability to handle stress, the presence of identity tags on government officials who provide services which include their data and position, clean look, its 
execution in accordance with schedules of reception of citizens);

- the availability of government services (the degree of awareness of citizens about how government services are provided and other significant conditions got through the media (radio, television, publications) and through the Internet, convenient for visitors schedule of government bodies authorized to provide government services, the optimal location of buildings of government bodies provided with public transport links, availability of access to government services for persons with disabilities);

- the location of government services provision (the number of windows through which the reception of citizens is executed, the level of information technology equipment infrastructure, installed information boards, availability of places to file an application with the necessary for this stationery, availability of services' waiting places, sanitary conditions of rooms).

This list of quality indicators is a general model that can be modified and adapted to the characteristics of different types of government services, depending on their specific features.

In this connection, it seems appropriate to introduce evaluation quality system of government services by citizens and their associations. It is an effective way to study the condition of actually provided services and allow focusing reformers' attention on weak points of this activity.

\section{Acknowledgments}

The article was written in the framework of State order of the Ministry of education and science of the Russian Federation, project "Inter-disciplinary socio-humanitarian studies in the context of innovative development and world relations" (project code 2232, 2014).

\section{References}

Order of the Ministry of Finance of the Russian Federation "On approval of the administrative regulations of the Federal Tax Service registration services of cash registers used by organizations and sole proprietors in accordance with the legislation of the Russian Federation" of 29.06.2012 \# 94n.

Order of the Ministry of Finance of the Russian Federation "On approval of the administrative regulations of the Federal Tax Service registration services of cash registers used by organizations and sole proprietors in accordance with the legislation of the Russian Federation" of 29.06.2012 \# 94n.

Order of the Ministry of Finance of the Russian Federation "On approval of the Administrative Regulations of the Federal Tax Service for the provision of government services for free informing of taxpayers, payers of charges and tax agents on existing taxes and charges, laws on taxes and charges and adopted in accordance with them regulations, calculation and payment of taxes and charges, rights and obligations of taxpayers, payers of charges and tax agents, the powers of tax authorities and their officials, as well as the reception of tax declarations (calculations) of 02.07.2012 \# 99n.

Order of the Ministry of Finance of the Russian Federation "On approval of the Administrative Regulations of the Federal Tax Service for the provision of government services for free informing of taxpayers, payers of charges and tax agents on existing taxes and charges, laws on taxes and charges and adopted in accordance with them regulations, calculation and payment of taxes and charges, rights and obligations of taxpayers, payers of charges and tax agents, the powers of tax authorities and their officials, as well as the reception of tax declarations (calculations) of 02.07.2012 \# 99n.

Order of the Health Ministry of Russia "On approval of the Administrative Regulations of the Federal Service for Labour and Employment of government registration services in the notification procedure of collective labor disputes concerning the conclusion, modification and implementation of agreements concluded at the federal level of social partnership and collective labor disputes in the organizations financed from the federal budget, as well as collective labor disputes in cases where, in accordance with the legislation of the Russian Federation to resolve a collective labor dispute strike can not be done " of 01.03.2012 \# 180n.

Order of Ministry of Finance of Russia "On approval of the Administrative Regulations of the Federal Tax Service of the government service to issue special stamps for marking tobacco products produced in the territory of the Russian Federation, special grade sample, document forms and rules governing the storage of special stamps stipulated by Resolution of the Government of the Russian Federation of 26.01. 2010 \# 27 and repeal of the order of the Ministry of Finance of the Russian Federation of 11.06 .2010 \# 59n" of 06.02.2013 \# 20N.

Order of the Ministry of Labour of Russia "On approval of the Administrative Regulations of the Pension Fund of the Russian Federation and its territorial bodies of the review service of the application for disposal (part of funds) of the mother (family) capital" of 29.10.2012 \# 346n.

Method of SERVQUAL; model of the quality of government services' evaluation, worked out in Canada under the name Common Measurement Tool (CMT) Date Views 22.11.2014 www.bagalau.kz.ru.

Fund "Public Opinion": "Citizens to a rendezvous with the state: the practice of providing services individuals and legal entities by government agencies." All-Russian monitoring of the implementation of administrative regulations. M., 2009. P. 609-690; Annual 
monitoring of the quality and accessibility of government services for citizens Date Views 22.11.2014 www.ar.gov.ru/gos_ uslugi_03_monitoring_kachestva_predostavleniya_gos_uslug / index.html.

Order of the Ministry of Health and Social Development of Russia "On approval of the Administrative Regulations of the Ministry of Health and Social Development of the Russian Federation for the provision of the government service of Russian Federation citizens' send for treatment outside the territory of the Russian Federation" of 19.12.2011 \# 1571n

The website of "Public Opinion Fund" Date Views 24.11.2014 www.fom.ru/politika/10439. 